\title{
Dossier: neuropsychiatrische beeldcollecties
}

In de tweede helft van de negentiende eeuw begonnen de eerste wetenschappers cinematografie in te zetten om bewegingen te analyseren en te bestuderen. Dit gebeurde op verschillende plekken in de wereld. In Parijs bijvoorbeeld werkte de fysioloog Étienne-Jules Marey samen met Albert Londe die later de fotograaf van Jean-Martin Charcot zou worden. En in Philadelphia ging Eadweard Muybridge in zee met de neuroloog Francis Xavier Dercum. Ze werkten gelijktijdig aan een methode om bewegingen te registreren en te analyseren. Eén van de resultaten was de chronophotographie, een visuele techniek die door middel van fotografische opnamen bewegingen in normale en pathologische omstandigheden registreerde en analyseerde. Na de rudimentaire ervaringen van Muybridge, Dercum, Marey en Londe namen neurologen deze nieuwe methoden (de chronofotografische methode, later gevolgd door de cinematografische techniek) voor bewegingsanalyse over en zetten ze veelvuldig in voor onderzoek. ${ }^{\mathrm{I}}$

Het afgelopen decennium zijn steeds meer beeldarchieven met neuropsychiatrisch materiaal teruggevonden. In 2002 volgde nieuw en spannend onderzoek naar de neuropsychiatrische artsen die deze wetenschappelijke en medische films en foto's maakten. Het doel van dit onderzoek was een beter begrip van de rol van de cinematografie in de ontwikkeling van de geneeskunde en in het bijzonder van de neuropsychiatrie. De eerste resultaten kwamen van Geneviève Aubert en Adriano Chio, twee neurologen met een grote interesse voor de geschiedenis van hun eigen vakgebied. In de loop van de tijd hebben zich meer onderzoekers bij dit tweetal gevoegd, met als uiteindelijk resultaat een groeiende onderzoeksgroep die zich richt op verschillende collecties met neurologische en medische film in Europa.

Deze nieuwe onderzoeksgroep heeft als doel om het wetenschappelijke en culturele netwerk onder de aandacht te brengen, waarbinnen cinematografie ingezet werd in het neurologisch onderzoek dat aan het begin van de twintigste eeuw ontstond in Europa. Het centrum van dit netwerk was Parijs, waar Jean-Martin Charcot in 1878 in het Salpêtrière ziekenhuis een studio voor medische fotografie begon. Albert Londe stond aan het hoofd van deze studio, die het centrum werd voor verbetering van fotografische apparatuur, gebruikt in de klinische praktijk en bedoeld om patiënten met neuropsychiatrische aandoeningen te bestuderen.

Het waren de leerlingen van Charcot, zoals Joseph Babinski en Pierre Marie die het belang van de afbeeldingen in de analyse van beweging inzagen. Het was hun verdienste dat ook andere Europese neurologen kennis maakten met de cinematograaf en de manier waarop ze dit apparaat in konden zetten voor hun onderzoek. Het resultaat was dat neurologen zoals Gheorghe Marinescu in Boekarest, Paul Schuster in Berlijn, Osvaldo Polimanti in Rome, Camillo Negro in Turijn, Vincenzo Neri in Parijs en Bologna, Paul Sainton in Parijs, Rudolf Magnus in Utrecht en Arthur Van Gehuchten in Leuven film inzetten met de wens hun onderzoek te verbeteren.

Dit dossier zal zich richten op vier collecties neuropsychiatrische films die recentelijk zijn 
teruggevonden en gerestaureerd. Het gaat hier om de films van Camillo Negro, Arthur Van Gehuchten, Vincenzo Neri en Rudolf Magnus en Gysbertus Rademaker. Het is een overzicht van het archiefwerk dat tot nu toe gedaan is binnen de onderzoeksgroep en dat hopelijk zal leiden tot verdere inzichten in dit zo interessante onderzoeksveld.

\section{Noten}

I Virgilio Tosi, Cinema before cinema - the origins of scientific cinematography, Sergio Angelini (trans.), A British Universities Film \& Video Council Publication, London 2005. 